\section{Atypical Mononuclear Cells in the Blood}

In $1898 \mathrm{~W}$. Türk ${ }^{1}$ was the first to describe the presence of atypical cells in the blood of patients with bacterial infections. Subsequently other authors have described such cells in a variety of conditions, and the term "atyoical mononuclear" cells was introduced to describe them because of their uncertain nature. After the introduction of a technique by R. Klima and colleagues ${ }^{2}$ for examining the buffy coat of centrifuged blood it was soon appreciated what a great variety of atypical cells the blood may contain.

Hyperbasophilic medium-sized lymphocytes, plasma cells, and primitive lymphoid cells appear in the blood after immunization, infection, hypersensitivity reactions, and the onset of autoimmune disease. There is now considerable evidence that these cells represent a circulating population of lymphoid cells derived from lymphoid tissue responding to antigenic stimulation. ${ }^{3}$ Reactive lymphoid cells have also been found in the blood of patients with Hodgkin's disease, their presence suggesting that immunological reactions are in progress, but it is unknown whether the reactions are against the tumour or some concurrent infection. ${ }^{4}$ The primitive lymphoid cells or "immunoblasts" which appear after immunization are a dividing population of large pyroninophilic blast cells, and work in sheep on similar cells has shown that at least some are capable of turning into plasma cells. ${ }^{5}$ The immunoblasts are present in the blood for only a short time before going to the lymph nodes to disseminate the immunological response. ${ }^{6}$ Measurement of an atypical mononuclear cell response in the blood has recently been used to detect homograft rejection after renal transplantation. ${ }^{78}$

Large numbers of proliferating mononuclear cells appear in the blood during certain viral infections, such as infectious hepatitis and glandular fever. These are thought to be the consequence of viral tranformation, and in cases of glandular fever the cells have been found to bear virus-induced antigens. ${ }^{9}$ They have a different morphological appearance and are different in character from immunoblasts.

Neoplastic cells can appear in the blood in a variety of malignant conditions. They have different properties from reactive cells and can usually be identified, but their identification can be difficult because they have no single feature which allows the diagnosis of malignancy to be made with confidence. This difficulty is compounded by the knowledge that primitive cells of lymphoid and bone marrow origin often appear normally in the blood in small numbers. In some diseases the difference between reactive and malignant cells is not clear. One such disease, known as Sézary syndrome, has recently been under detailed investigation, and the work illustrates some of the difficulties. ${ }^{10}$

The Sézary syndrome is a rare disease characterized by chronic skin lesions associated with a mononuclear infiltrate and the appearance of large numbers of abnormal mononuclear cells in the peripheral blood. The classical features of the disease are usually confined to the skin, and consist of infiltrative lesions with pruritus and erythroderma. The disease is thought to be related to mycosis fungoides and the lymphomas, and transition to a lymphoma has been observed in some patients. The morphological appearance of the cells, the presence of periodic-acid-Schiff-positive coarse granules in the cytoplasm, and their response to phytohaemagglutinin all suggest that the mononuclear cells are of lymphoid origin.
The cells responding to phytohaemagglutinin stimulation had three chromosomal counts, of 46, 76, and 98-99 (normal, 46). In addition, the cells in the last two groups had large marker chromosomes, and these cell lines were almost certainly neoplastic. Most of the cells were grossly abnormal and only about $10 \%$ of the mitoses had a normal diploid complement. The patient did, however, receive cytotoxic therapy during the five years before the chromosomal analysis was made, and this may have affected the result. The work provides further evidence that a normal transformation response to phytohaemagglutinin does not preclude malignancy in the cell concerned, but it does suggest that the cell is likely to be lymphoid in origin.

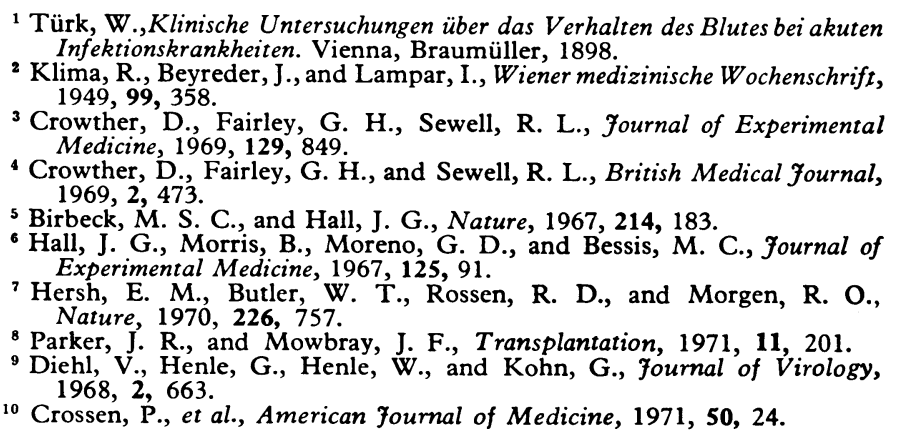

\section{Trail of Suspicion}

For many months the Employment and Social Services Subcommittee of the Expenditure Committee (a Government body) has been taking evidence on the use to which some of the social services are put. Among other things it wants to find out whether N.H.S. facilities are being used-or misused -for private patients. Allegations of many abuses have been put before the committee by representatives of the Medical Practitioners' Union ${ }^{1}$ and the Junior Hospital Doctors' Association. ${ }^{2}$ A delegation from the B.M.A. gave evidence on 29 June and submitted a memorandum. ${ }^{3}$ The committee has also received some other evidence with a bearing on the issue.

The nurses are brought into this as well. Invited by the committee to supply evidence on the use of private patients of Health Service facilities, the Royal College of Nursing found that none had come its way. Pressed by the committee to provide a nursing view, as it were, the college devised a questionnaire to obtain some information from its members. Mr. J. C. Angell draws attention to this document in a letter at page 585 this week, and the questions themselves are reproduced at page 591 . We are informed it has recently been sent to members of the college's council and of some of its committees, and that the ordinary members will also be given the opportunity of filling it in if any of them wishes to do so.

Whether or not private patients in hospital are receiving treatment in a way that amounts to an abuse of the Health Service is almost entirely a matter for the consultants in whose care they lie. It is true there may be circumstances in the patient's management, and in the context of this inquiry, that are the concern of the sister or other nurses looking after him, but the nurses' responsibility for them can only be exceedingly small in comparison with the consultant's nverriding responsibility for the case. An obligation rests with the Royal College of Nursing to see that this line is carefully drawn, for if it is not the professional relationship between doctors and nurses could be harmed. 
Any Government has the clear duty to see that a service it provides is not being misused by the people who work in it or the citizens it is intended to serve. Abuse cannot be allowed in medicine above all, for people's lives and health are at stake. But the danger of an inquiry of this sort is that it can make perfectly innocent people suspicious of each other's conduct and motives. The notion that nurses are somehow being set to spy on doctors is so ridiculous that it can be instantly rejected. Yet some strange things are going on in relation to the inquiry. A representative of the M.P.U. was asked, for instance, whether the Union had made attempts to quantify the extent to which part-time consultants do less than the nine-elevenths which they are contracted to do. ${ }^{1}$ "Yes," he replied, "we have indeed. I cannot say where they are doing it because it would put them on their guard, but I know a couple of hospitals where this sort of thing is going on and where people are keeping track on particular doctors." "Organized by whom?"- "By themselves." It would be a sad day for medicine if this manner of inquiry became widespread.

\footnotetext{
1 Expenditure Committee (Employment and Social Services Subcommittee), Minutes of Evidence, 22 June 1971. London, H.M.S.O., 1971.

${ }^{2}$ Expenditure Committee (Employment and Social Services Subcommittee), Minutes of Evidence, 16 June 1971. London, H.M.S.O., 1971.

Expenditure Committee (Employment and Social Services Subcommittee) Minutes of Evidence, 29 June 1971. London, H.M.S.O., 1971.
}

\section{Hepatic Vein Occlusion}

Until the mid-years of this century the aetiology of hepatic vein occlusion (the Budd-Chiari syndrome) was largely unknown. Such established causes as renal carcinoma, primary tumours of the inferior vena cava, and polycythaemia rubra vera accounted for no more than $30 \%$ of recorded cases. ${ }^{1}$ Since then pyrrolizidine alkaloids (found in plants of the genera Senecio, Crotalaria, and Heliotropium $)^{2} 3$ have been shown to produce occlusion of the smallest tributaries of the hepatic venous system (veno-occlusive disease), and urethane ${ }^{4}$ and massive irradiation of the liver ${ }^{5}$ have also been found to do so.

At least when the larger veins are blocked the vascular lesions would seem most often, if not always, to be thrombotic in nature. It is not surprising, therefore, that oral contraceptives, now established as a cause of venous thromboembolism and cerebral thrombosis, ${ }^{6}$ have also been associated with occlusion of hepatic veins. A. M. Hoyumpa and colleagues $^{7}$ have recently added two cases to the six previously recorded. ${ }^{8-13}$ Five of these eight patients had been on preparations containing more than $0.05 \mathrm{mg}$ oestrogen and two on low-oestrogen-containing products; in one the proportion of oestrogen and progestogen was not stated. The duration of exposure to an oral contraceptive ranged from two weeks to eight years. Hoyumpa and his colleagues conclude that "although direct evidence is lacking, the possibility of a causal relationship between hepatic vein occlusion and the use of oral contraceptives is worthy of consideration."

The clinical picture produced by hepatic vein occlusion associated with an oral contraceptive is similar to that due to other causes. Abdominal swelling from ascites is the most characteristic clinical feature, this being accompanied as a rule by epigastric pain and hepatomegaly. Nausea and anorexia are frequent, while jaundice is uncommon. An unusual method of presentation is as an acute abdominal emergency, with shock and pain overshadowing the symptoms and signs of liver disease. One of the cases associated with oral contraceptives fell into this category. ${ }^{13}$ Portal hypertension may develop. 9

In the investigation of suspected hepatic vein occlusion hepatic venography has been of value. ${ }^{14}$ The syndrome gives no characteristic pattern of response to liver function tests, the alkaline phosphatase level being the one most often raised. Needle biopsy has proved its worth, the characteristic picture being congestion and loss of cells in the centres of the lobules. In long-standing cases fibrosis, and later still nodular regeneration, may be present. Since it is the mediumsized and larger veins which appear to be affected when an oral contraceptive is incriminated, the venous thrombi themselves may not be seen in biopsy material. The histological features, therefore, may not be distinguishable from those seen in heart failure and constrictive pericarditis. ${ }^{14}$ The presence of red blood cells between rather than in the liver sinusoids is described as characteristic of blockage of the hepatic venous outflow, ${ }^{15}$ but whether this feature may also occur in heart failure is not clear.

The prognosis in hepatic vein occlusion is poor, and while survival of from one to several years is fairly common few cases of complete recovery are on record. Of the eight cases associated with oral contraceptives, however, two have apparently recovered..$^{7-10}$ Recanalization of thrombi and the opening up of collateral channels in the adventitia of occluded veins and in the diaphragm is sometimes seen at necropsy, so that re-establishment of the circulation is in theory possible. Surgical removal of the obstruction has been reported in three cases not due to contraceptives. In one a haematoma pressing on the hepatic veins was evacuated, ${ }^{16}$ and the veins were dilated by probing in another case. ${ }^{17}$ Both of these were attributed to trauma. Finally, a case in which thrombus at the ostia of the hepatic veins was successfully removed has been mentioned. ${ }^{18}$ But to judge by the extent of the thrombosis usually seen at necropsy, it seems unlikely that many cases would be amenable to such surgical treatment.

${ }^{1}$ Parker, R. G. F., Medicine (Baltimore), 1959, 38, 369.

2 Selzer, G., and Parker, R. G. F., American fournal of Pathology, 1951, 27, 885 .

3 Bras, G., Jeliffe, D. B., and Stuart, K. L., Archives of Pathology, 1954, 57, 285 .

- Meacham, G. C., Tillotson, F. W., and Heinle, R. W., American fournal of Clinical Pathology, 1952, 22, 22 .
of

5 Reed, G. B., and Cox, A. J., American Fournal of Pathology, 1966, 48, 597. - Vessey, M. P., and Doll, R., British Medical fournal, 1969, 2, 651.

Hoyumpa, A. M., Schiff, L., and Helfman, E. L., American fournal of Medicine, 1971, 50, 137.

- Ecker, J. A., McKittrick, J. E., and Failing, R. M., American fournal of Gastroenterology, 1966, 45, 429.

- Sterup, K., and Mosbech, J., British Medical fournal, 1967, 4, 660.

${ }^{10}$ Somayaji, B. N., Eeles, G. H., Paton, A., and Parker, R. G. F., British Medical fournal, 1968, 1, 53 .

11 Rothwell-Jackson, R. L., British Medical fournal, 1968, 1, 252.

12 Clubb, A. W., and Giles, C., British Medical fournal, 1968, 1, 252.

${ }_{13}$ Grayson, M. J., and Reilly, M. C. T., British Medical fournal, 1968, 1, 512.

14 Clain, D., Freston, J., Kreel, L., and Sherlock, S., American fournal of Medicine, 1967, 43, 544 .

${ }^{15}$ Leopold, J. G., Parry, T. E., and Storring, F. K., Fournal of Pathology, $1970,100,87$

16 Ekström, G., and Hagberg, S., Acta chirurgica Scandinavica, 1957, 112, 107.

7 Nicoloff, D. M., Fortuny, I. E., and DeWall, R. A., Fournal of Thoracic and Cardiovascular Surgery, 1964, 47, 225.

is Oakley, C., in Cryer, R. J., Proceedings of the Royal Society of Medicine $1970,63,289$. 